\title{
Subject Visits Supplemental Qualifiers Dataset
}

National Cancer Institute

\section{Source}

National Cancer Institute. Subject Visits Supplemental Qualifiers Dataset. NCI Thesaurus.

Code C147253.

A dataset containing supplemental information, specifically non-standard variables, to parent records in the subject visits domain. 